\title{
Epidemiological Characteristics of Schistosoma mansoni Infection in Rural and Urban Endemic Areas of Minas Gerais, Brazil
}

\author{
Márcia N Amorim/ ${ }^{+}$, Ana Rabello, Rabindranah Loyola Contreras*, \\ Naftale Katz
}

Centro de Pesquisas René Rachou- FIOCRUZ, Av. Augusto de Lima 1715, 30190-002 Belo Horizonte, MG,

Brasil *Faculdade de Veterinária, Universidade Federal de Minas Gerais, Belo horizonte, MG, Brasil

To compare the epidemiological profile and socioeconomic factors associated to the infection by Schistosoma mansoni in a rural and an urban endemic area a cross-sectional study was performed in Água Branca de Minas (rural area) and Bela Fama (urban area), both situated in the State of Minas Gerais, Brazil. Two hundred and eighty eight individuals were surveyed in the rural area and 787 in the urban area. Water contact and socioeconomic questionnaires were used to identify risk factors for the infection. The prevalences of $38.8 \%$ and $9.7 \%$ and the geometric mean of eggs per gram of faeces of 117.8 and 62.3 were found in the rural and urban areas, respectively. By multivariate statistical analysis age groups over nine years old and previous specific treatment were associated with the infection in rural area. In urban area age over nine years old, low quality housing, weekly fishing and swimming were associated after adjustment by logistic regression.

Key words: schistosomiasis mansoni - epidemiology - urbanization - socioeconomic variables

The expansion of schistosomiasis mansoni into Brazilian urban areas have grown to great proportions during the last five decades. Rural dwellers suffer from successive policy modifications regarding country work. This applies to a large number migrated in big cities as well.

The direct relation between migration and introduction of parasitosis in Brazilian cities has been the subject of evaluation (Barreto 1967, Suassuna \& Coura 1969, Marques 1979, Carvalho et al. 1988).

Migration has become an important factor in parasitosis transmission, a specially schistosomiasis, in other parts of the world. Benyouseef et al. (1973) identified a $13.6 \%$ infection rate by Schistosoma mansoni among migrants of Dakar in Africa. High indexes of prevalence were found among migrants of agricultural colonies in Ethiopia (Kloos 1985) and Sudan (Bella et al. 1980).

However, migration is not the only cause for these indexes of schistosomiasis transmission. The absence of sanitary infrastructure and appropriate water supplies and drainage, low educational levels of people and difficult access to public health services are conclusive in the characterization of the places where the migrant populations agglom-

${ }^{+}$Corresponding author. Fax: +55-31- 295.3115

Received 13 November 1996

Accepted 23 May 1997 erate (Bradley 1968, Silva 1985, Mott et al. 1990).

Socioeconomic factors which involve the population of underdeveloped countries, are determinants in schistosomiasis transmission. In rural areas, due to the absence of appropriate infrastructure, people using water from streams to perform domestic or professional activities are the target population for infection (Dalton 1976, Lima e Costa et al. 1987).

In urban areas, the most frequent reasons for water contact are related to leisure (Barreto 1991, Guerra 1992).

The socioeconomic characterization of rural and urban areas and its influence on the transmission of $S$. mansoni infection is the main interest of this study. In order to compare epidemiological features and risk factors of the infection, we carried out a cross-sectional study in two endemic areas, one rural and one urban, both in the State of Minas Gerais, Brazil.

\section{MATERIALS AND METHODS}

Studied areas, socioeconomic and malacologic survey - Água Branca de Minas is a typical rural community in the municipal district of Comercinho in the northeast of Minas Gerais, $701 \mathrm{~km}$ distant from Belo Horizonte, the capital of the state. It has a population of 302 inhabitants. Most economic activity is agrarian with the cultivation of sugar cane, rice and corn.

Bela Fama, a suburb of Nova Lima is situated 
in the metropolitan region of Belo Horizonte and has 800 inhabitants. The main economic activities in this region are the commercial and the mining.

Using a standardized questionnaire, age, sex, birthplace, occupation, school level, quality of houses and water supply were registered. Information on water contact was obtained individually or from responsible authorities, in case of children under 10 years old. The reasons and frequency of water contacts from a period up to six months before the date of the interview were investigated. Snails were collected from all the hydric collections.

Parasitological and clinical diagnosis - All participants received a faeces collector, identified with the person's name and a registration number. From each fecal sample, two slides were prepared and examined by the Kato-Katz method (Katz et al. 1972). Individuals which presented eggs in their faeces were classified as positive cases, the remaining were assigned as negative controls.

Clinical examination and classification was performed according to the criteria adopted by Lima e Costa et al. (1985) using the clinical exam: Type I - intestinal; Type II - hepatointestinal; Type III - hepatosplenic.

Data analysis - The variance analysis was used for the comparison of the logarithmic means. The chi-square and Fisher exact tests were used for the proportions. Odd ratios were used to determine the strength of association between the independent variables and the dependent one (Armitage \& Berry 1987). To determine the independent effect of the variables, logistic regression was performed (Breslow \& Day 1980). The criteria for inclusion of variables in the logistic model was proposed by Greenland (1989). Differences in the 95\% level of confidence were considered to be significant (Armitage \& Berry 1987). The analyses was done using the statistical packages of EPIINFO (Dean et al. 1990) and MULTILR (Campos Filho \& Franco 1989).

\section{RESULTS}

Descriptive results - During the study, 302 inhabitants (139 men and 149 women) were identified in Água Branca de Minas. Stool examination was performed on $288(95 \%)$ individuals. They also answered the socioeconomical questionnaire. A clinical examination and a survey on water contact was completed for 281 (93\%) and 267 (86\%) individuals, respectively.

A prevalence of $38.8 \%$ and a geometric mean 117,8 eggs per gram of faeces (epg) among the infected people was found, both peaking in the 20 to 29 years old age group (Fig.). Two percent of the clinically examined patients presented the clini- cal form Type III.

Eighty-eight per cent of the population reported contact with stream water during the last six months. The reasons for water contact were: crossing streams $(50 \%)$, getting water $(45 \%)$; bathing $(32 \%)$, washing clothes $(31 \%)$, swimming $(22 \%)$, working on the vegetable garden (17\%), and fishing $(12 \%)$.

In Bela Fama, 787/800 (98\%), (392 men and 395 women) of the residents answered the socioeconomic questionnarie and delivered faeces sample. A prevalence of $9.7 \%$ and a geometric mean of 62.3 eggs were observed, which peaked in the 15 to 19 age group (Fig.). The clinical form Type III was not identified.

The reasons for water contact, reported by 665 $(85 \%)$ individuals were: swimming/playing (42\%), fishing (15\%), crossing the stream (8\%), washing clothes $(6 \%)$, cleaning plumbs $(4 \%)$, falling in the stream $(3 \%)$, working in agriculture $(2 \%)$, working in mining, getting water, and/or washing and bathing $(1 \%)$.

Univaried analysis - In the rural area, statistically significant associations between the infection and the risk factors existed in over nine years old age group, and water contact while fishing.

In the urban area, males gender, over the age of nine years old, previous treatment with schistosomicide, living in poor quality house, nonqualified workers and swimming and fishing in streams were significantly associated with infection.

Multivaried analysis - From the variables which were used for the multivaried logistic regression model, the following presented association with infection: (a) rural area - age over 10 years old, and previous treatment with schistosomicide (Table I); (b) urban area- over 10 years old, of poor quality housing, weekly swimming and daily or weekly fishing (Table II).

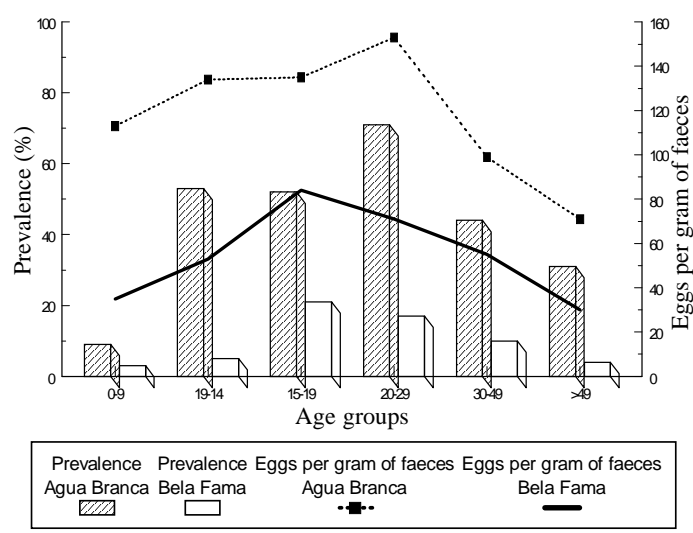

Prevalence and geometric mean of eggs per gram of faeces by age groups in Água Branca de Minas, rural endemic area and Bela Fama, urban endemic area, State of Minas Gerais, Brazil. 


\section{TABLE I}

Variables independently associated with the infection in the population of Água Branca de Minas, State of Minas Gerais, Brazil, after adjustment by the logistic model

\begin{tabular}{lrrr}
\hline Variables & OR & CI (95\%) & P \\
\hline Age 10-29 years old & 9.643 & $3.889-23.910$ & 0.0000 \\
Age older than 29 & 4.813 & $1.935-11.972$ & 0.0007 \\
Treated with & & & \\
schistosomicide & 0.381 & $0.197-0.738$ & 0.0042 \\
\hline
\end{tabular}

OR: odds ratio; CI: confidence interval; P: probability

\section{TABLE II}

Variables independently associated with the infection in the population of Bela Fama, State of Minas Gerais, Brazil, after the adjustment by the logistic model

\begin{tabular}{lrrr}
\hline Variables & OR & CI $(95 \%)$ & $\mathrm{P}$ \\
\hline $\begin{array}{l}\text { Age 10-29 } \\
\text { Age }^{3} \text { 30 }\end{array}$ & 4.697 & $1.542-14.305$ & 0.0065 \\
$\begin{array}{l}\text { Living in houses } \\
\text { of poor quality }\end{array}$ & 1.804 & $1.008-3.230$ & 0.0471 \\
Fishing daily & 14.473 & $3.487-60.082$ & 0.0002 \\
Fishing weekly & 6.751 & $3.506-12.999$ & 0.0000 \\
Swimming weekly & 3.721 & $1.954-7.089$ & 0.0001 \\
\hline
\end{tabular}

OR: odds ratio; CI: confidence interval; P: probability

\section{DISCUSSION}

The identification of risk factors for the infection by $S$. mansoni contributes to a better understanding of the transmission process and for the definition of control programs in particular localities. In this study, we evaluated the epidemiological characteristics and the risk factors for infection, comparing urban and rural areas, analyzing the influence of the urban environment in the transmission of schistosomiasis mansoni in Minas Gerais.

In the rural area, a medium level of prevalence and intensity of the infection was observed. A hepatosplenic clinical form was present in a small portion of the population. Most of the studies showed a similar prevalence. Peak prevalence and intensity of infection appeared in the 20 to 29 years old age group, typical of areas with low to medium endemicity.

Age appeared to be the factor which most influenced the transmission of schistosomiasis in this area. Socioeconomic factors did not show an association with infection. This might be explained by the very similar living conditions among all the inhabitants of the locality. Low socioeconomic standard was shown by low quality of housing in $94 \%$ of the population. Local houses did not have an appropriate structure for walls, flooring, roofing or even adequate sanitation facilities.

In the urban area, the leisure activities (swimming and fishing) were associated with $S$. mansoni infection. This is a common fact in urban areas, considering that houses generally have piped water. It was also observed that in the urban locality under study migration did not present any relation with the presence of schistosomiasis, which usually occurs in cities which attract workers from rural areas (Gryseels \& Ngimbi 1983, Barreto 1991). This suggests that infection was introduced a long time ago in this region and that the present cases are autochthonous. The peak of prevalence and geometric mean of eggs was in men of 15 to 19 years old. This corresponds to the age group which most uses water for swiming and fishing.

Socioeconomical conditions in the urban area studied demonstrate that $69 \%$ of the population live in better quality housing and $95 \%$ receive piped water. The possible factor which provided conditions for schistosomiasis transmission in Bela Fama was the fact that most human feces entered the stream which crosses the district thus transmitting disease to swimmers.

These results suggest that in urban areas the influence of the socioeconomic level is a determinant in the transmission of schistosomiasis and that the absence of leisure options leads poor inhabitants of these areas to search for streams or lakes to have fun, giving rise to a large risk of being infected by $S$. mansoni.

\section{REFERENCES}

Armitage PA, Berry G 1987. Statistical methods in medical research. Blackwell Scientific Publications, Oxford, $559 \mathrm{pp}$.

Barreto ML 1991. Geographical and socioeconomic factors relating to the distribution of Schistosoma mansoni infection in an urban area of north-east Brazil. Bull WHO 69: 93-102.

Barreto MP 1967. Movimentos migratórios e sua importância na epidemiologia de doenças parasitárias no Brasil. Rev Soc Bras Med Trop 1: 91-102.

Bella H, Marshall TFC, Omer AHS, Vaughan JP 1980. Migrant workers and schistosomiasis in the Gezire, Sudan. Trans R Soc Trop Med Hyg 74: 36-39.

Benyoussef A, Cutler JL, Baylet R 1973. Migration et urbanisation. Un etude collective au Senegal. Bull WHO 49: 517-537.

Bradley D 1968. Predicting the epidemiological consequences of changing water resources. Part II. A comparative approach to suburbanization. East Afr Med J 45: 334-340.

Breslow NE, Day NE 1980. Statistical Methods in Cancer Research. IARC, Scientific Publication, 350 pp. 
Campos Filho NBS, Franco EL 1989. A microcomputer program for multiple logistic regression by inconditional and conditional maximum likelihood methods. Am J Epidemiol 129: 439-444.

Carvalho OS, Rocha RS, Massara CL 1988. Primeiros casos autóctones de esquistossomose mansoni em região do noroeste do estado de Minas Gerais. Rev Saúde Públ 22: 237-239.

Dalton PR 1976. A socioecological approach to the control of Schistosoma mansoni in St. Lucia. Bull WHO 54: 587-595.

Dean AG, Dean JA, Burton AH, Dicker RC 1990. EPIINFO, version 5.01: a word processing data base statistics program for epidemiology on microcomputers. USD, Georgia, $367 \mathrm{pp}$.

Greenland S 1989. Modeling and variable selection in epidemiologic analysis. Am J Public Health 79: 340349

Gryseels B, Ngimbi P 1983. Further observations on the urban Schistosoma mansoni focus in Linshasa, Zaire. Ann Soc belge Med trop 63: 341-346.

Guerra HL 1992. Epidemiologia da esquistossomose manosni em São José do Acácio, MG. Análise multivariada dos fatores associados à infecção. Variáveis sócio-demográficas e contatos com águas naturais. Belo Horizonte, 116 pp.

Katz N, Chaves A, Pellegrino J 1972. A simple device for quantitative stool thick-smear technique in schistosomiasis mansoni. Rev Inst Med Trop São Paulo
14: 397-400.

Kloos H 1985. Water resources development and schistosomiasis ecology in the awash valley, Ethiopia. Soc Sci Med 20: 609-625.

Lima e Costa MFF, Rocha RS, Leite MLC, Carneiro RG, Colley D, Gazzinelli G, Katz N 1987. A multivariate analysis of socio-demographic factors, water contact patterns and Schistosoma mansoni infection in an endemic area in Brazil. Rev Inst Med Trop São Paulo 33: 58-63.

Lima e Costa MFF, Rocha RS, Magalhães MHA, Katz N 1985. A clinico-epidemiological survey of schistosomiasis mansoni in a hyperendemic area in Minas Gerais state (Comercinho, Brazil). I. Differences in the manifestations of schistosomiasis in the town centre and in the evirons. Trans $R$ Soc Trop Med Hyg 79: 539-545.

Marques AC 1979. Migrações internas e as grandes endemias. Rev Brasil Malariol D Trop 31: 137-158.

Mott KE, Desjeux P, Moncayo A 1990. Parasitic diseases and urban development. Bull WHO 68: 691698.

Silva LJ 1985. Crescimento urbano e doença. A esquistossomose no município de São Paulo (Brasil). Rev Saúde Públ São Paulo 19: 1-7.

Suassuna A, Coura JR 1969. Esquistossomose mansoni no Estado da Guanabara, aspectos epidemiológicos relacionados às migrações internas. Rev Soc Bras Med Trop 74: 347-354. 